\title{
SCALABRINI E SEU LEGADO
}

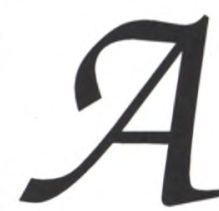

revista TRAVESSIA, em seus dezoito anos de existência, manteve seu olhar sempre voltado para a razão de ser de quem a mantém - o migrante! Neste ano de 2005, quando a Congregação dos Missionários de São Carlos/Escalabrinianos celebra o Centenário da morte de seu fundador, o bem-aventurado João Batista Scalabrini, abre seu espaço para um olhar ad intra, sem, porém, descuidar do foco. Não se trata de um balanço retrospectivo, nem seria possível fazê-lo aqui, mas apenas de alguns flashes do legado de Scalabrini no Brasil, entrecruzando o migrante e o olhar da pastoral.

Antes, porém, aos que não o conhecem, duas palavras. Nasceu em 1839, bem ao norte da Itália. Com 36 anos, foi sagrado bispo da diocese de Piacenza, próxima à industrializada Milão. Vivenciou, no campo socioeconômico, os efeitos da revolução industrial; no campo político, o processo de consolidação do Estado-Nação italiano e, no campo eclesial, o forte embate entre os que percebiam as profundas mudanças em curso e os que se aferravam à velha ordem. "O mundo caminha e nós não podemos ficar para trás" é uma das frases que melhor resume sua postura. Sua visão, porém, no âmbito da Igreja, consolida-se apenas no Concílio Vaticano II - a necessidade de dialogar com a modernidade.

Baixa estatura, excelente oratória, personalidade firme, muito inteligente e de faro aguçado, além de uma sensibilidade enorme, são traços que o caracterizaram. Foi definido como homem de ação e do diálogo. Sempre que se deparava com problemas no campo social, buscava encaminhar soluções. Organizou cozinha popular para socorrer os famintos; fundou um instituto em favor dos surdo-mudos; promoveu a criação de cooperativas de produção e consumo; caixas rurais para financiamento e o banco católico Sto. Antonino. Valorizava a comunicação: criou jornais e incentivava que outros o fizessem. Às paróquias, solicitava que efetuassem levantamentos da situação sócio-religiosa da população, bem como constituíssem equipes com o objetivo de suscitar iniciativas de promoção humana, social e cultural. Com relação aos migrantes sazonais do arroz, articulou uma comissão interdiocesana encarregada de efetuar uma pesquisa para saber quantos eram (aproximadamente $170 \mathrm{mil}$ ), conhecer as condições de trabalho e propor soluções. Escreveu "O socialismo e a ação do clero", defendendo o direito ao trabalho, maior participação nos lucros, direito à greve, à educação, pensão por velhice e/ou invalidez, prevenção à insalubridade.

Pronunciou inúmeras conferências, sempre muito concorridas. Defendeu a participação dos católicos nas eleições, proibidos de fazê-lo pela Cúria Romana, o que lhe causou fortes dissabores. A chamada Questão Romana, que sonhava ver resolvida, rendeu, entre ele e seu amigo de peito Geremia Bonomelli, bispo de Cremona, um acervo de 700 correspondências. São esses alguns aspectos da sua atuação social. Mas, o maior legado decorre do campo da migração. Em 1887, fundou uma Congregação de missionários para acompanhar os italianos que se dirigiam para a América, bem como uma associação de leigos para fazer frente, principalmente, nos portos de embarque, às ações dos que chamou de "agenciadores de carne humana" (diríamos, hoje, coyotes), mas também para acompanhar os migrantes na travessia atlântica e no desembarque.

Ao Parlamento italiano, dominado por anti-clericais, apresentou projeto de lei no tocante à emigração. Rejeitado, inicialmente, anos depois transformou-se em lei. Ao Papa, solicitou que fosse criada uma Comissão para todas as migrações. Scalabrini foi sim, um homem do seu tempo, mas do ponto de vista da mobilidade humana, o ultrapassou, ao afirmar: "Para o migrante a pátria é a terra que lhe dá o pão".

Em 1901 visitou os migrantes e as missões nos EUA e, em 1904, onde permaneceu por cinco meses, o Brasil. Aqui, sobretudo em São Paulo, iniciou-se uma presença ditada pelo processo migratório - ir onde o imigrante italiano estava - em termos práticos, uma pastoral supra-paroquial. Mas o peso da história rapidamente absorveu esta atuação para o âmbito de paróquias territoriais, diferentemente de outras plagas onde se estabeleceram paróquias pessoais. Este dado, mais tarde somado ao ingresso de brasileiros na Congregação, concomitantemente ao advento das maciças migrações internas, constituem o pano de fundo dos textos aqui apresentados.

A iniciativa de um projeto novo, em São Paulo, no final dos anos 1930, visando resgatar a originalidade de uma atuação junto aos italianos é descrita pelo pe. Gelmino. $\mathrm{O}$ embate em torno da ampliação da finalidade a todos os migrantes aparece no depoimento do pe. Giovanni. A consolidação da mudança reflete-se nos demais textos. Alberto e Alvírio mergulham no drama vivido pelos migrantes internos no final da década de 1960 . Pe. Alfredo traça a memória de um passado recente quanto ao envolvimento do Seminário Maior João XXIII e do CEM com as questões sociais. Maria Aparecida enfoca a ação da Pastoral junto aos migrantes temporários do interior paulista - uma ação itinerante no espaço da mobilidade permanente.

Dirceu Cutti 